\title{
Thirty-Eight New Records for Algal Species of Iraq's Marshes
}

\author{
Ahmed Aidan Al-Hussieny, Lamyia Abed Thijar \\ Center of Water Research, Department of Environment and Water Research, Ministry of Science and \\ Technology, Baghdad, Iraq \\ Email: Ahmed.edan85@yahoo.com
}

Received 2 January 2016; accepted 17 January 2016; published 21 January 2016

Copyright (C) 2016 by authors and OALib.

This work is licensed under the Creative Commons Attribution International License (CC BY). http://creativecommons.org/licenses/by/4.0/

(c) (i) Open Access

\begin{abstract}
Mesopotamian marshes in Iraq occupy a vast network of wetland at southern region. This study contains the description of many algal species that were identified in the marshes of Iraq, and based on the study thirty-eights new records will be added to the Algal Flora list of Iraq. Samples were collected at (10) stations, situated on Hammar, Chebaish and Hawizeh marshes in Iraq in May 2014. Thirty-eight new records for algal species of marshes were determined. Among these algal species, there were 6 Chlorophyta, 7 Cyanophyta, 1 Chrysophyta, 15 Bacillariophyta, 7 Euglenophyta and 2 Pyrrophyta. The dominating of species depended on water salinity, pH, and electrical conductivity in addition to biomass of identified algae.
\end{abstract}

\section{Keywords}

Algal, Marshes, New Records, Biomass, Chlorophyta, Cyanophyta, Chrysophyta

Subject Areas: Biodiversity

\section{Introduction}

Iraqi southern marshes from a large triangular region are bounded by three major southern cities: Nasiriyah to the west, Amarah to the northeast, and Basrah to the south. Such specific wetlands of the southern part of Iraq play a vital role in the maintenance of biodiversity in the middle east primarily because of their large size, the richness of their aquatic vegetation and their isolation from other comparable system [1]. The southern marshes of Iraq are the natural areas for appropriate growth and reproduction of algae, also once famous for their biodiversity and cultural richness. The Tigris and Euphrates have created about 15,000 $\mathrm{km}^{2}$ of wetlands known as Mesopotamian marshes in Iraq. These wetlands comprise a complex of interconnected shallow freshwater lakes and marshlands, which are considered the most extensive wetland ecosystem in the middle east [2]. The Mesopotamians marshes of Iraq have been all destroyed by the year 2000. Earlier assessments suggested that poor water quality, the presence of toxic materials, and high saline soil conditions in the drained marshes would pre- 
vent their ecological restoration and doom the reestablishment of the marsh Arab culture of fishing and agriculture. However the high volume of good quality water entering the marshes from Tigris and Euphrates Rivers, a result of two record years of snowpack melt in Turkey and Iran, allowed 39\% of the former marshes to be reflowed by September 2005 [3]. Research into algal diversity in marshes still remains at initial stage and knowledge of regional algal diversity is far from exhaustive; the algal communities of the natural marshes of Iraq are better known but still sporadically studied. [4] has discussed the water chemistry and ecology of marshes and listed 100 species at Shatt Al-Arab and Gulf areas. Algal species were listed from several parts: [5] listed 289 species, [6] listed 96 species, [7] listed 128 species, [8] listed 164 species, [9] listed 275 species, [10] listed 120 species and [11] listed 75 species. In Iraq few studies dealt with morphology and taxonomy of phytoplankton at marshes of Iraq [12] [13]. Present work aimed to study the systematic account for algae and to add new records species of algae for the first time in marshes of Iraq.

\section{Materials and Methods}

Samples had been brought from 10 stations at Hammar, Hawizah and Chebaish marshes (Al-eiz, Al-kasrrah, Um Al-Nia'aj, Abo-athbah, the right of impoundment, Ouda, Baghdadia, north Abo-zarraq, Alkarmashia river and Kamessia canal). For the quantitative study subsurface water samples (1 liter) were collected from each station. One liter of each sample was taken in a measuring cylinder mixed with $2 \mathrm{ml}$ of Lugol's iodine solution (as preservative), allowed to sediment for 10 days and was then concentrated to $100 \mathrm{ml}$. The same steps were repeated for one week to sediment the last $100 \mathrm{ml}$ to $10 \mathrm{ml}$ [14]. A drop of preserval material was placed on a clean coverslip dried and cleaned with hot concentrated Nitric acid, followed by use of the microtransect method for counting diatoms (Bacillariophyceae), where as for the other species the haemocytometer method was used [15]. Detailed studies were made under a compound microscope with camera and microns $(\mu \mathrm{m})$ were used to describe the diameter (L: length and $\mathrm{W}$ : width) of each examined taxon and photographs were taken also [12]. Identified taxa were checked with the checklist of [16]-[20] and determined as new taxa for southern marshes of Iraq. Taxonomy of algal species controlled with [21]-[24].

Physical analysis

Total dissolved solid, electrical conductivity, and $\mathrm{pH}$ were measured by using pH-EC-TDS meter (HANNA Instruments). The expression of results were $\mu \mathrm{S} / \mathrm{cm}$ for conductivity, salinity were measured using [25].

\section{Description of the Study Area}

o Al-Hammar marshes are a large complex of wetlands in Iraq that are part of the Tigris-Euphrates system along Mesopotamian which also encompass the Hawizah and central marshes. The Hammar marsh formerly covered area of $2800 \mathrm{~km}^{2}$ of permanent wetland tending to over $4500 \mathrm{~km}^{2}$ in certain season. The Hammar marshes stretched between Nasiriyah and Basrah and were located south of the Euphrates River which formed their principal source.

o The Al-Hawizah marshes are a complex of marshes that straddle the Iraq and Iran border. The marshes are fed by two branches of the Tigris River (the Al-Musharrah and Al-Kahla) in Iraq and Karkheh River in Iran. The Hawizah marsh is critical to the survival of the central and Hammar marshes which also make up the Mesopotamian marshes because they are a refuge for species that may recolonize or reproduce into the other marshland.

o Al-Chebaish marshes are located east of Nasiriyah in Iraq and they are extension to Abu-zark and Hammar marshes and fed by Tigris and Euphrates Rivers (Figure 1).

\section{Results}

The variables of physical parameters $\mathrm{pH}$, electrical conductivity, TDS and salinity are given in Table 1.

A total number of new records for algal flora of southern marshes of Iraq are 38 (6 Chlorophyta, 8 Cyanophyta, 16 Chrysophyta, 7 Euglenophyta, 1 Pyrrophyta). Taxa are listed below:

\section{1-Division: Euglenophyta.}

Class: Euglenophyceae.

Order: Euglenales.

Familia: Euglenaceae.

Genus: Trachelomonas. 


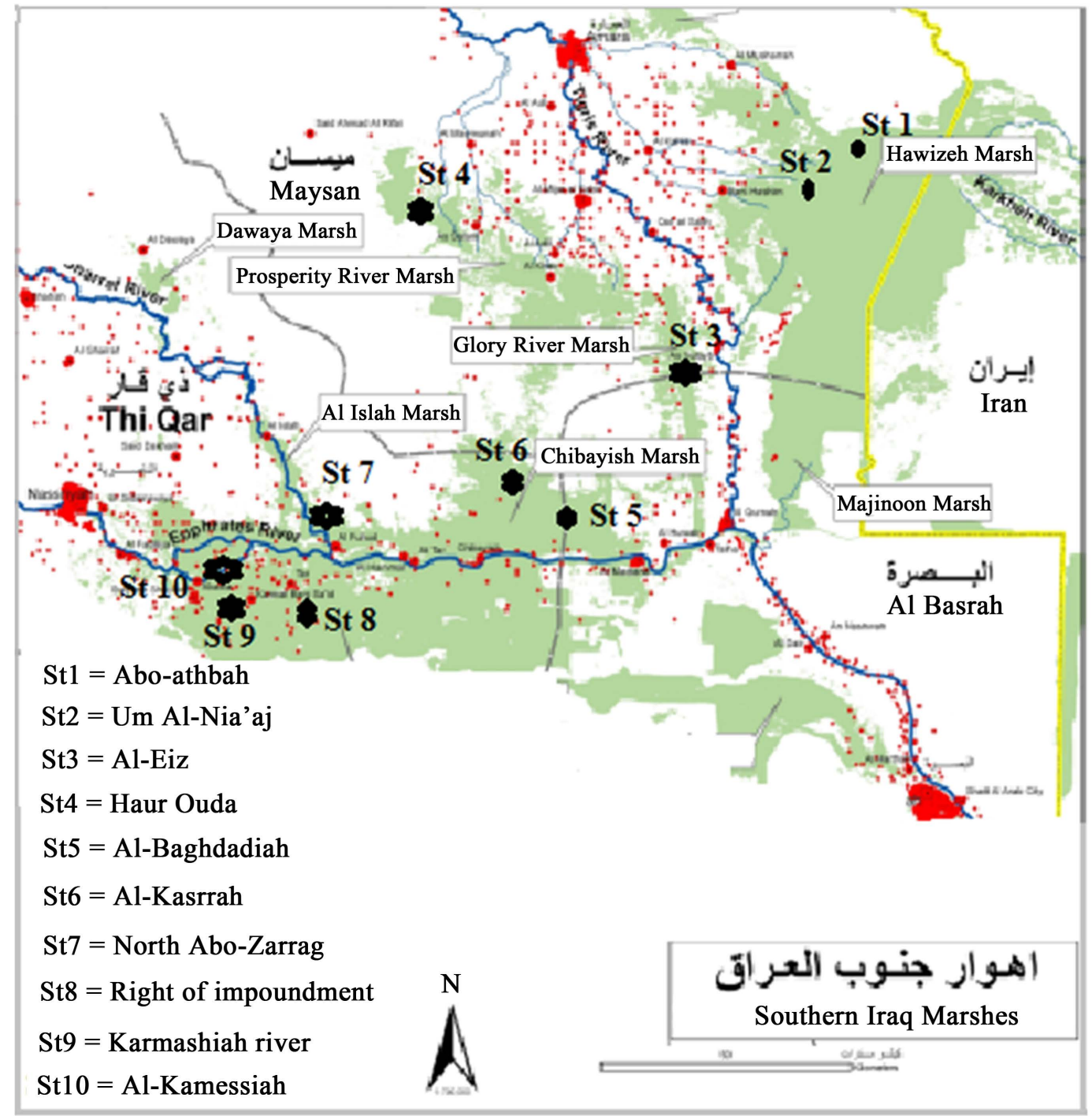

Figure 1. Map of study sites of the southern marshes of Iraq.

Table 1. Some physical parameters for the study locations.

\begin{tabular}{|c|c|c|c|c|}
\hline Parameters & Sal. \%o & Electrical conductivity $\mu \mathrm{S} / \mathrm{cm}$ & TDS mg/l & $\mathrm{pH}$ \\
\hline St1-Abo-athbah & 1.2 & 2.51 & 1322 & 7.72 \\
\hline St2-Um Al-Nia’aj & 0.4 & 1206 & 638 & 7.94 \\
\hline St3-Al-Eiz & 0.4 & 1325 & 691 & 7.88 \\
\hline St4-Haur Ouda & 2.7 & 5.14 & - & 7.71 \\
\hline St5-Al-Baghdadiah & 2.9 & 5.5 & - & 7.37 \\
\hline St6-Al-Kasrrah & 2.3 & 4.44 & - & 7.81 \\
\hline St7-North Abo-Zarrag & 0.8 & 1950 & 1015 & 7 \\
\hline St8-Right of impoundment & 1.3 & 2.67 & 1472 & 7.7 \\
\hline St9-Karmashiah river & 0.9 & 2.19 & 1131 & 7.91 \\
\hline St10-Al-Kamessiah & 3.1 & 5.78 & - & 7.8 \\
\hline
\end{tabular}

(-) out of illustration. 
1-Trachelomonas cylindrica. Ehrenberg.

Test oblong-cylindrical broadly, rounded at the posterior end but somewhat flattened anterior, wall smooth, yellowish and flagellum opening surrounded by a short collari, test 8 - $10 \mu$ in diameter 14.8 - $20 \mu$ long (Image 1).

2-T. dubia. Swir.

Test cylindrical broadly, rounded posterior truncate at the anterior end and abruptly narrowed to form a short cylindrical neck, wall smooth, thickened at the base of the collar, test 11 - $14 \mu$ in diameter 26 - $28 \mu$ long. Euplanktonic and Tychoplanktonic. Wis. (Image 2).

3-T. playfairii. Deflandre.

Test broadly ellipsoid or ovate and rounded both anterior and posterior, flagellum aperture in a short curved collar wall smooth and almost color less or light yellow, test 19 - 21 (23) $\mu$ in diameter, 23 - $30 \mu$ long, Tychoplanktonic and Euplanktonic. Wis. (Image 3).

4-T. pulchella. Drezepolski.

Test oval to ovoid, small, flagellum aperture with a short ring-like collar, wall uniformly beset with blunt, wart-like roughening, test $5-17 \mu$ in diameter, about $15 \mu$ long. Tychoplankter. Wis. (Image 4).

Image 1. Trachelomonas cylindrica. Ehrenberg. 400×.

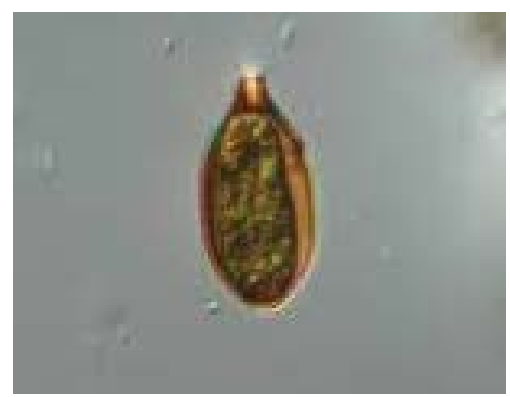

Image 2. T. dubia. 400×.

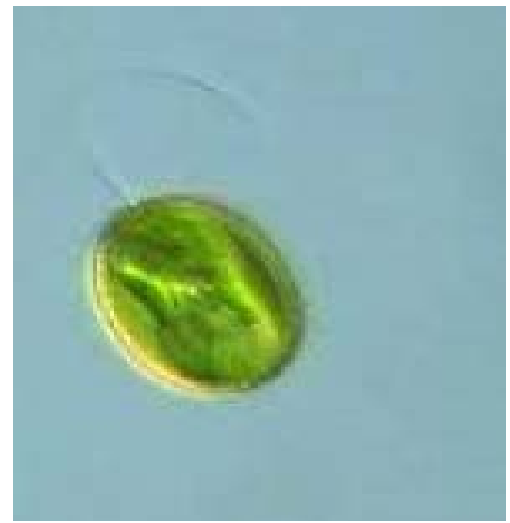

Image 3. T. playfairii. Deflandre. 400×. 
5-Phacus pyrum. Ehrenb. Stein.

Broadly rounded anterior but with 2 papilla between which the flagellum emerges, periplast spirally ribbed, papamylon bodies 2 ring-like plates, laterally situated, cells 7 - $21 \mu$ in diameter, 27 - $30 \mu$ long (Image 5).

6-P. helikoides. Pochmann.

Cells fusiform or elongate fusiform-pyriform, twisted throughout their entire length, cells 39 - $54 \mu$ in diameter. 70 - $120 \mu$ long (Image 6).

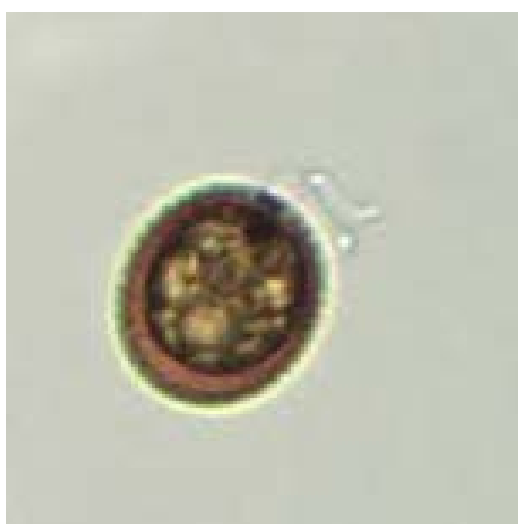

Image 4. T. pulchella. 400×.

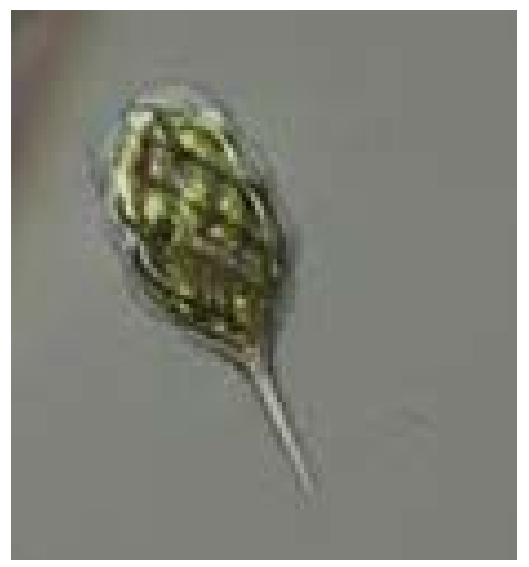

Image 5. Phacuspyrum. Ehrenb. Stein. 400×.

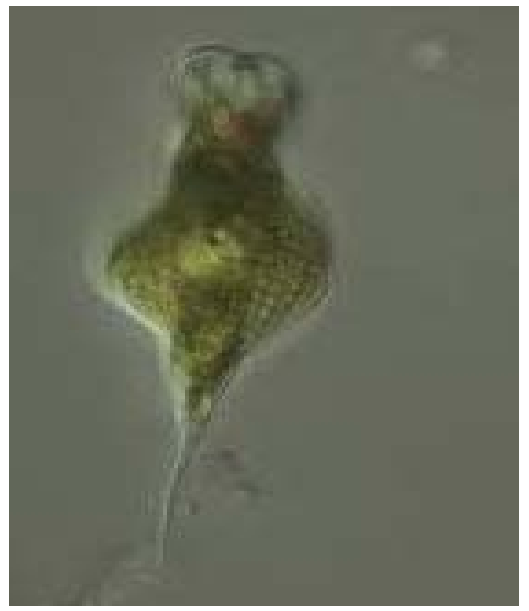

Image 6. P. helikoides. Pochmann.400×. 
7-P. crenulata. Prescott.

Cell ovoid-pyriform, posterior extended to form a gradually tapering. Sharp-pointed caudus, cells $14-15 \mu$ in diameter, 34 - $36 \mu$ long (Image 7).

\section{2-Division: Chlorophyta.}

1-Class: Chlorophyceae.

Order: Oedogoniales.

Familia: Oedogoniaceae.

Genus: Characium.

8-Characiumhookeri. Hansgirg. (Reinsch).

Cells mostly gregarious on Cyclops, club-shaped to subcylindric, stipe long or short without an attaching disc, chloroplast 1, with 1 - 3 pyrenoids, cells $9-12 \mu$ in diameter, 27 - $30 \mu$ long. On Cyclops in lakes and ponds, euplanktonic and tychoplanktonic, Wis. (Image 8).

2-Class: Chlorophyceae.

1-Order: Ulotrichales.

Genus: Geminella.

9-Geminella crenulatocollis. Prescott.

Uniseriate filaments of irregularly ovoid, subquadrate or oblong cells with ernarginate, crenulate or wary lateral walls, truncate or broadly rounded at the poles with folds and ridges sometimes present in the lateral walls. Cells inclosed by a broad gelatinous sheath and arranged in linear pairs but often evenly spaced Chloroplast an irregularly shaped, folded parietal plate which makes an almost complete cylinder within the wall, often showing a ridge or wing like flange extending radially toward the. Wall cells $12-15 \mu$ in diameter, $18-24 \mu$ long (Image 9).

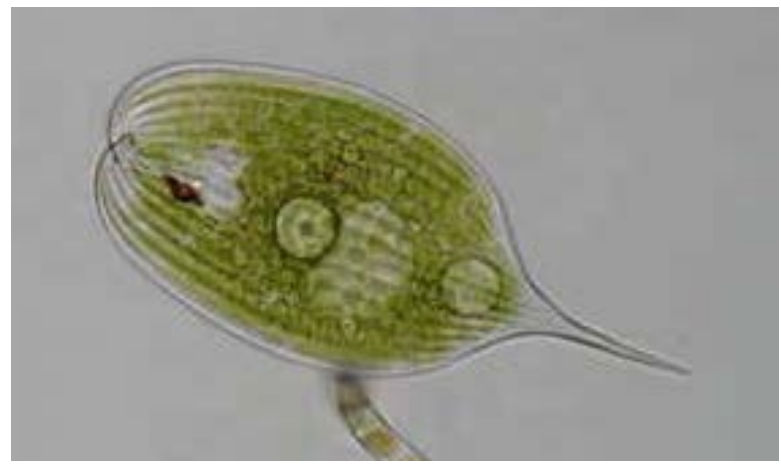

Image 7. P. crenulata. Prescott. 400×.

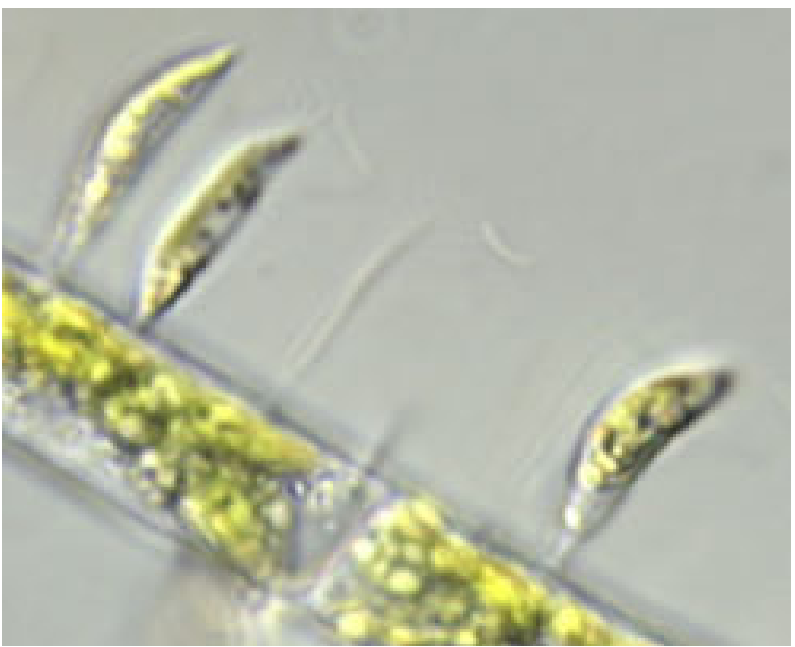

Image 8. Characium hookeri. 400×. 


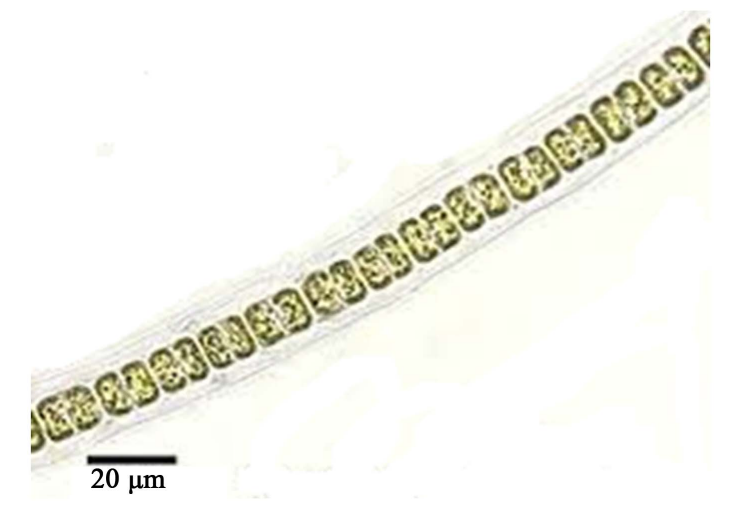

Image 9. Geminellacrenu latocollis. Prescott. 400×.

\section{2-Order: Volvocales.}

\section{Family: Chlamydomonadaceae.}

\section{Genus: -Chlamydomonas.}

10-Chlamydomonas eipiphytica. G. M. Smith.

Cells spherical to nearly pyriform, anteriorly narrowed into a papilla-like beak. Cells becoming non-motile, adherent to the colonial mucilage of microcystis without losing flagella. Chloroplast a thin parietal cup, pigment-spot lacking-cells 7 - $8 \mu$ in diameter, 8 - $9 \mu$ long. common in several lakes. Wis. (Image 10).

\section{3-Order: Oedogoniales.}

\section{Family: Oedogoniaceae.}

Genus: -Oedogonium.

11-Oedogonium decipiens. Var. africanum.

Vegetative cells capitellate, 8 - $14 \mu$ in diameter, 20 - $65 \mu$ long, Oogonia 28 - $35 \mu$ in diameter, 23 - $38 \mu$ long, Oospores 23 - $34 \mu$ in diameter, 21 - $30 \mu$ long. Andro sporangium $9.2 \mu$ in diameter, $8 \mu$ long. Antheridia $8 \mu$ in diameter. Common in swamps and lakes. Mich. Wis. (Image 11).

12-Oedogonium pratense. Transeau.

Macrandrous, dioecious, vegetative cells cylindric, 9.2 - $17 \mu$ in diameter, 24 - $95 \mu$ long. Oogonia solitary, globose or subpyriform-globose, operculate, division median, 33 - $44 \mu$ in diameter, 35 - $50 \mu$ long. Wall smooth, 32 - $40 \mu$ in diameter, 28 - $42 \mu$ long. Antheridia $10-14 \mu$ in diameter, 13 - $18 \mu$ long (Image 12).

13-Oedogonium pringsheimii. Cramer.

Macrandrous, dioecious, vegetative cells cylindric, $14-20 \mu$ in diameter, $43-100 \mu$ long. Oogonia $1-6$, globoseor subovate-globose, operculate, division, 35 - $43 \mu$ in diameter, 36 - $46 \mu$ long. Wall smooth, thick, 30 $37 \mu$ in diameter, 35 - $46 \mu$ long. Antheridia 10 - $16 \mu$ in diameter, 6 - $9 \mu$ long (Image 13).

3-Division: -Chrysophyta.

Class: Xanthophyceae.

Genus: Chlorochromonas.

14-Chlorochromonas minuta. Lewis.

Cells pyriform or cordate, with 2 flagella of unequal length attached at the broad anterior end, which is slightly concave, cell wall lacking, protoplast containing 2 elongate-ovate and somewhat curved chromatophores, characteristics as described for the genus, cells 4.5 - $9.5 \mu$ long culture from lake Mendota (Image 14).

\section{4-Division: -Cyanophyta.}

1-Class: -Myxophyceae.

Order: -Chroococcales.

Familia: -Chroococcaceae.

Genus: Glaucocystis.

15-Glaucocystis oocystiformis. Prescott.

Cells solitary (or in colonies), broadly elliptic With nodular thickenings of the cell wall at the poles, Chromatophores numerous, irregular pads at the periphery of the cell about a central, Spherical, Colorless vacuole, cells 20 - $27.3 \mu$ in diameter, 40 - $45 \mu$ long. This species differs from the others in the shape of cell, the form of the Chromatophores and in its possession of polar nodules. Whether the absence of colonial association or the re- 


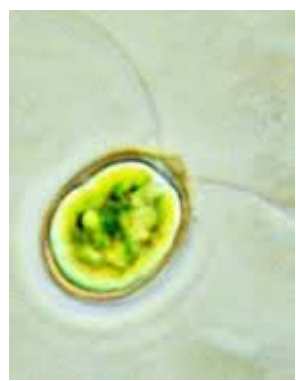

Image 10. Chlamydomonas eipiphytica. G.M.Smith. 400×.

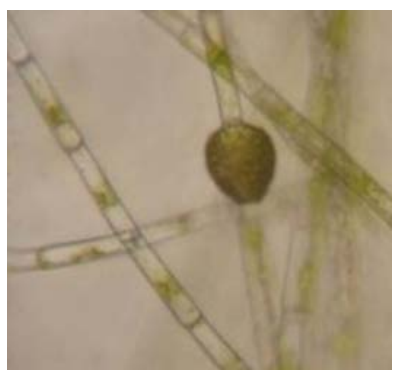

Image 11. Oedogonium decipiens. Var. africanum. 400×.

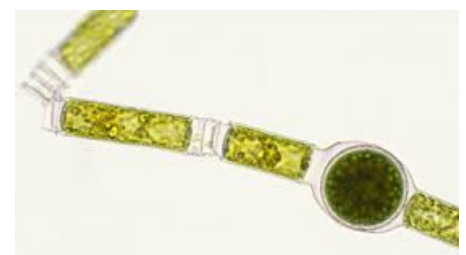

Image 12. Oedogonium pratense. Transeau. 400×.

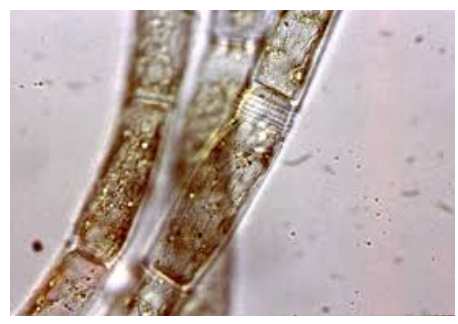

Image 13. Oedogonium pringsheimii. Cramer. 400×.

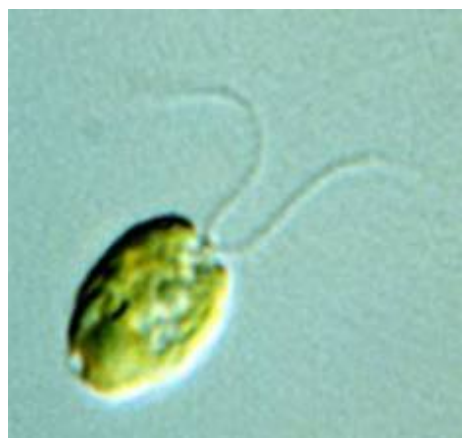

Image 14. Chlorochromonas minuta. Lewis. 400×. 
tention of autospores within the mother cell wall is a constant feature is under mind but in all cases observed the cells were solitary (Image 15).

2-Class: -Cyanophyceae.

1-Order: -Chamaesiphonales.

Familia: -Dermocarpaceae.

Genus: Dermocarpa.

16-Dermocarpa olivacea.

Plants forming a small or expanded and hemispherical layer, sporangia broad pyriform to spherical with a marked stalk like elongation at the base, 9.5 - $17 \mu$ broad, 13 - $25 \mu$ long, wall thick, lamellated, endospores many. spherical (Image 16).

2-Order Nostocales

Family Microchaetaceae

Genus Camptylonemopsis.

17-Camptylonemopsis lahorensis.

Thalluswodly, bright bluish green or bluish brown, terrestrial, partly embedded in mud and partly above it, sheath in conspieuous, thin and hyaline in the embedded region and firm, thick and lamellose, lightly adhering and brown in the exposed portion, the trichome bluish green 6 - $9 \mu$ broad, slightly constricted at the joints. 12 $21 \mu$ long and 7 - $9 \mu$ wide, spores 7 - $11 \mu$ long and 5 - $7 \mu$ wide (Image 17).

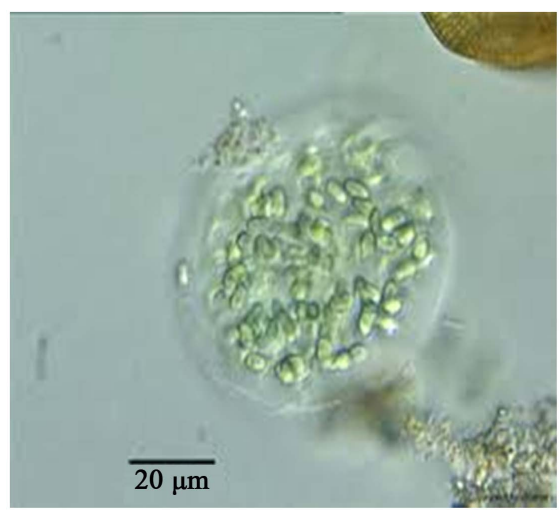

Image 15. Glaucocystis oocystiformis. Prescott. 400×.

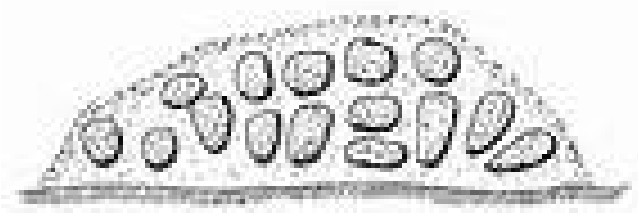

Image 16. Dermocarpa olivacea. 400×.

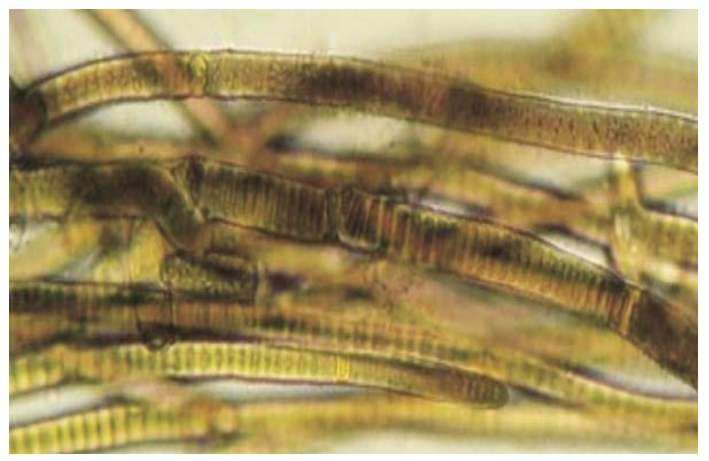

Image 17. Camptylonemopsis lahorensis. 400×. 


\section{3-Class: Myxophyceae. \\ Order: Nostocacales. \\ Family: Nostocaceae. \\ Genus: -Anabaena.}

18-Anabaena iyengarii. Bharadwaja.

Trichoma single or irregularly curved, 5.2 - $6.3 \mu$ broad, end-cell conical with rounded apex, cells barrel-shaped, as long as broad, or slightly shorter or longer than broad, heterocysts barrel-shaped, rarely spherical, 7.3 - $8.4 \mu$ broad and 7.3 - $10.5 \mu$ long, spores ellipsoidal often in long or short chains, rarely single on both sides of the heterocysts, $8.4-10.5 \mu$ broad and $10.5-21 \mu$ long, epispore thick, smooth and yellowish brown (Image 18).

19-A. fertilissima. Rao, C.B.

Trichoma single, straight or bent with almost rounded end cells, up to $350 \mu$ long, 5 - $5.6 \mu$ broad, at the apex $4 \mu$ broad, cells barrel-shaped, 4.8 - $8 \mu$ long, heterocysts almost spherical, $6.4-8.4 \mu$ broad, spores in long chains often making the wide trachoma sporogenous, adjoining the heterocysts but formed centrifugally, almost spherical with a smooth hyaline outer wall, 4.8 - $8 \mu$ broad and 3.2 - $8.8 \mu$ long (Image 19).

20-A. oryzae. Fritsch.

Thallus soft, green, gelatinous, membranous, trachomas short, straight, densely aggregated, generally paralled cells 2.5 - $3 \mu$ broad, more or less barrel shaped, $1^{1 / 2}-2$ times as long as broad, heterocyst steriminal and intercalary, broader than the vegetative cells, 3 - $3.5 \mu$ broad, terminal ones conical and twice longer than broad, intercalary ones, single (Image 20).

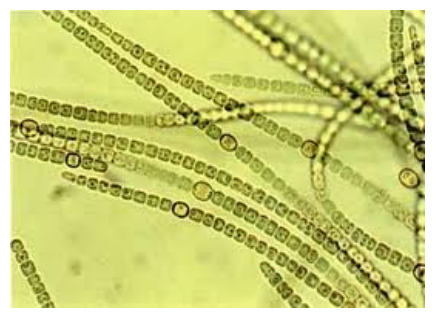

Image 18. Anabaena iyengarii. Bharadwaja. 400×.

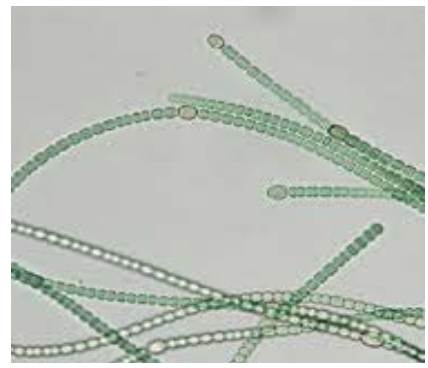

Image 19. A. fertilissima. Rao, C.B. 400×.

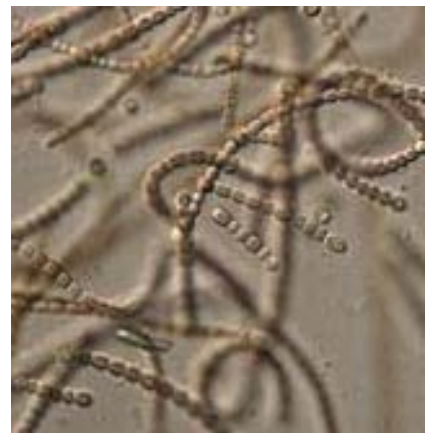

Image 20. A. oryzae. Fritsch. 400×. 
21-A. gelatinicola. Ghose.

Thallus thick gelatinous, trichome mostly solitary, spirals densely arranged and coiled not screw like, sometimes straight, cells subspherical 6 - $7.5 \mu$ broad, apex a cute, heterocysts 7 - $8 \mu$ broad, spherical, spores in series away from the heterocysts, spherical, about $14 \mu$ diameter (Image 21).

5-Division: Pyrrophyta.

Class: -Dinophycea.

Order: -Peridiniales.

1. Family: -Glenodiniaceae.

Genus: -Glenodinium.

22-Glenodiniumkulczynskii. (Wolosz.) Scbillor.

Cells broadly ovoid or nearly round as seen in ventral view, flattened in polar view, the dorsal margin broadly convex, epitheca with 1 apical, 3 intercalary, and 6 precingular plates, hypotheca with 6 postcingular and 2 antapical plates, longitudinal furrow extending to the apex of the hypocone, cell $30-31.5 \mu$ in diameter, $35 \mu$ long. Tychoplankter. Wis. (Image 22).

2. Family: Peridiniaceae.

Genus: -Peridinium

23-Peridinium cinctum. var. Lemmermannii

Cells $62-70 \mu$ in diameter, 56 - $70 \mu$ long, 52 - $53 \mu$ thick, a variety in which the right antapical plate is distinctly larger than the left. Euplanktonic and tychoplanktonic. Mich. Wis. (Image 23).

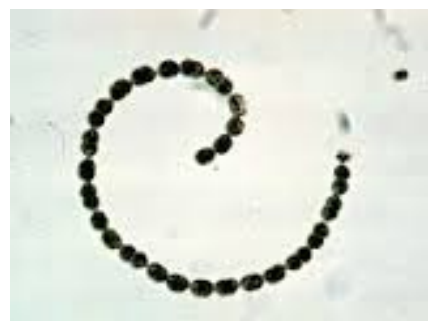

Image 21. A. gelatinicola. 400×.

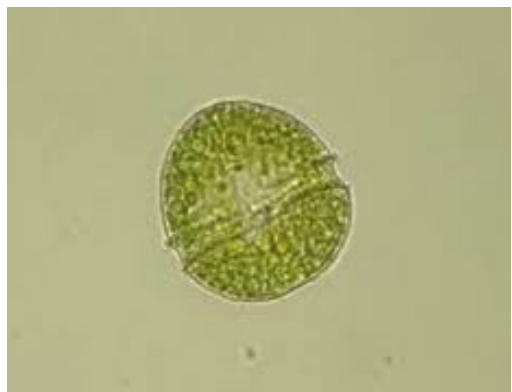

Image 22. Glenodiniumkulczynskii. (Wolosz.) Scbillor. 400×.

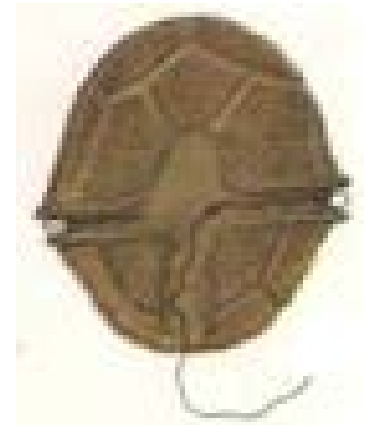

Image 23. Peridinium cinctum. 400×. 


\section{6-Division: Bacillariophyta.}

Class: Diatomatae.

Order: Pennales.

1-Family: Achnanthaceae.

Genus: -Achnanthes.

24-Achnanthes inflate. Kutz.

Cells 30 - $65 \mu \mathrm{m}$ long. 10 - $15 \mu \mathrm{m}$ wide. Stries 9 - 11 in $10 \mu \mathrm{m}$ (Image 24).

2-Family: Coscinodiscaceae.

\section{Genus: -Coscinodiscus.}

25-Coscinodiscus lacustris

Very characteristic with its large pits, Irregularly radially aligned and are not protected strictly a reticule provision has strong transverse ripple the surface area of the valve is very remarkable, the diameter varies from 20 to $50 \mu \mathrm{m}$ the peripheral teeth very slightly prominent, 5 to 7 in $10 \mu \mathrm{m}$ (Image 25).

3-Family: Eunotiaceae.

Genus: -Eunotia.

26-Eunotia alpine. Naegeli. Hust.

Cells long 25 - $120 \mu \mathrm{m}$, larger 1.5 - $2.5 \mu \mathrm{m}$ and fine stries 16 - 21 in $10 \mu \mathrm{m}$ (Image 26).

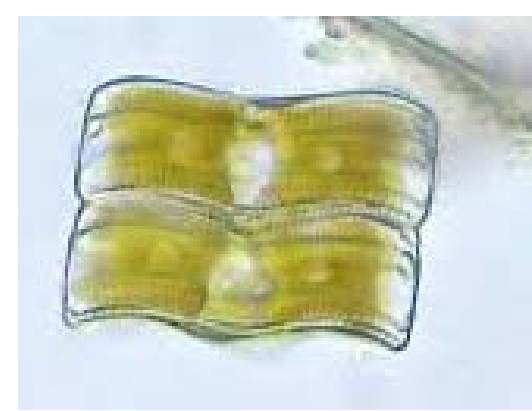

Image 24. Achnanthes inflate. 1000×.

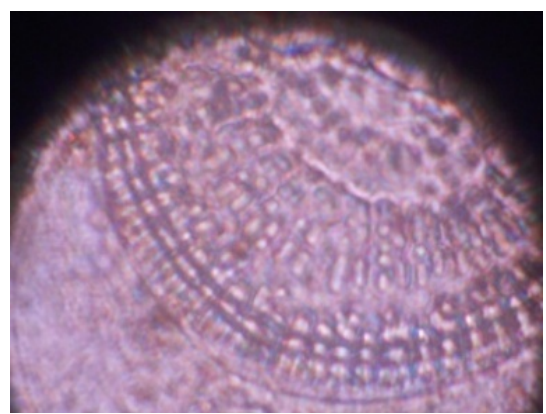

Image 25. Coscinodiscus lacustris. 1000×.

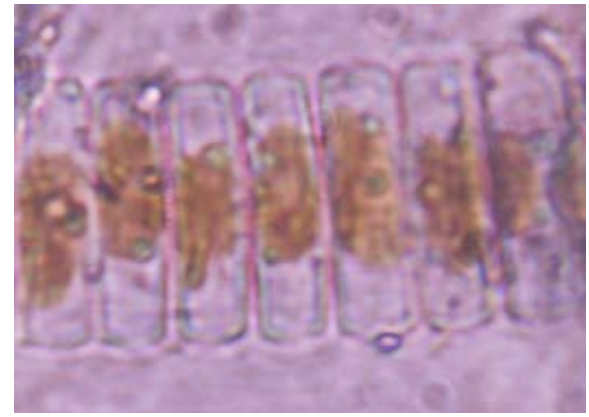

Image 26. Eunotia alpine. 400×. 
4-Family: Naviculaceae.

Genus: -Navicula.

27-Navicula bacilloides. Ehe.

Cells 15 - $18 \mu \mathrm{m}$ long and 7 - 8 large. Stries fines 23 - 25 in $10 \mu \mathrm{m}$ (Image 27).

28-N. goppertiana. Bleisch. Grun.

Cells 10 - $30 \mu \mathrm{m}$ long and 5 - $8 \mu \mathrm{m}$ large. stries 16 - 18 in $10 \mu \mathrm{m}$ (Image 28).

29- $N$. standeriella. Krasske.

Cells long 10 - $25 \mu \mathrm{m}$ and large 5 - $7 \mu \mathrm{m}$. stries 20 - 22 in $10 \mu \mathrm{m}$ (Image 29).

30-N. saprophila. Lange-Bertalot.

Cells long 6 - $8 \mu \mathrm{m}$, large 3 - $4 \mu \mathrm{m}$ and stries 50 - 60 in $10 \mu \mathrm{m}$ (Image 30).

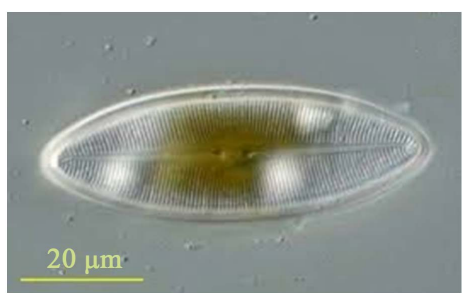

Image 27. Navicula bacilloides. 1000×.

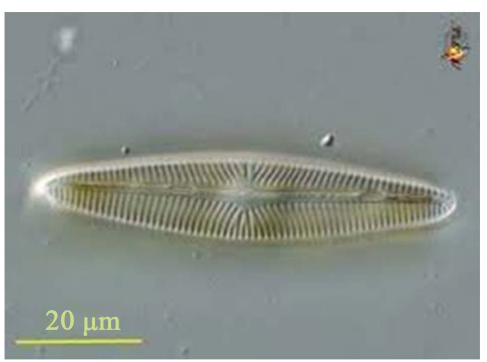

Image 28. N. goppertiana. 1000×.

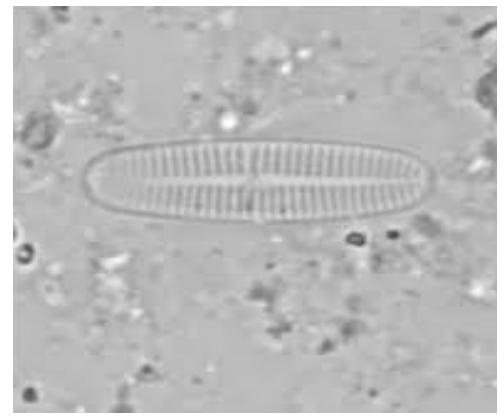

Image 29. N. standeriella. Krasske. 1000×.

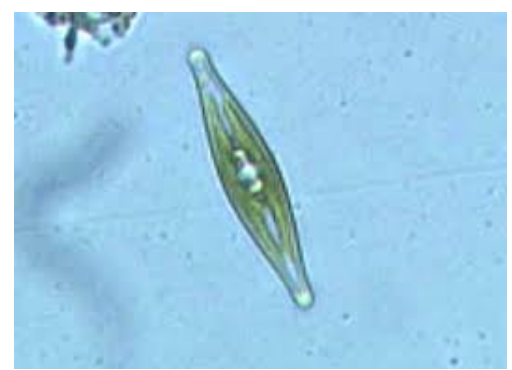

Image 30. N. standeriella. 1000×. 
31-N. seminulum. Grunow.

Cells long 5 - $15 \mu \mathrm{m}, 3$ - $4 \mu \mathrm{m}$ large and stries 20 - 22 in $10 \mu \mathrm{m}$ (Image 31).

32-N. tantula. Hustedt.

Cells 7 - $16 \mu \mathrm{m}$ long and 2.5 - $3.5 \mu \mathrm{m}$ large. All fine Striesradiating from 27 to 30 in $10 \mu \mathrm{m}$ (Image 32).

5-Family: Bacillariaceae.

Genus: -Nitzschia.

33-Nitzschia comunis. Rabenhorst.

Cells long 20 - $35 \mu \mathrm{m}$. large 4 - $5 \mu \mathrm{m}$ and stries 11 - 14 in $10 \mu \mathrm{m}$ (Image 33).

34- $N$. fruticosa. Hustedt.

Cell long 20 - $55 \mu \mathrm{m}$, large 3 - $4 \mu \mathrm{m}$, and 14 - 15 fibulae in $10 \mu \mathrm{m}$ stries (Image 34).

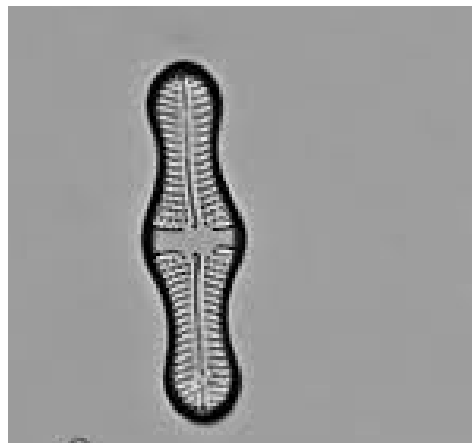

Image 31. N. seminulum. 1000×.

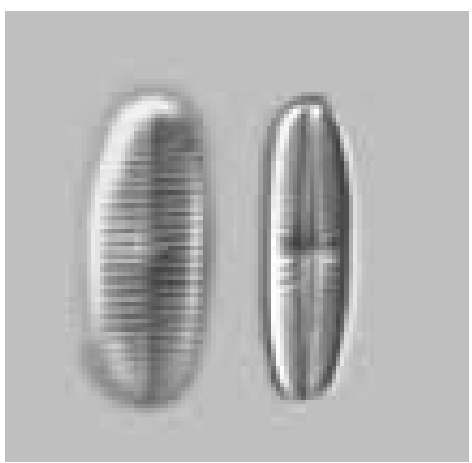

Image 32. N. tantula. $1000 \times$.

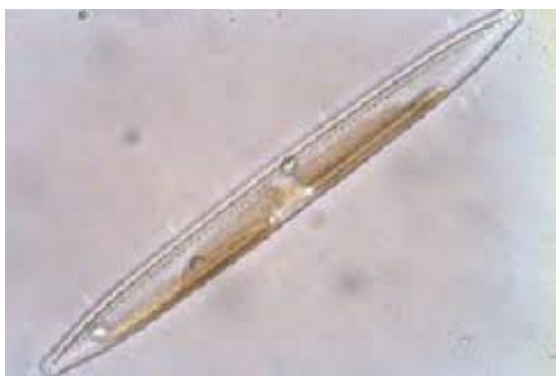

Image 33. Nitzschiacomunis. 1000×.

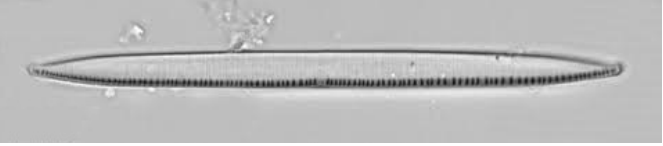

Image 34. N. fruticosa. 1000×. 


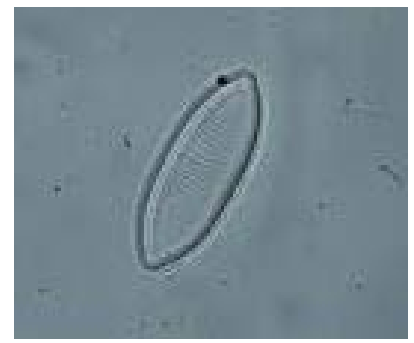

Image 35. N. littoralis. 1000×.

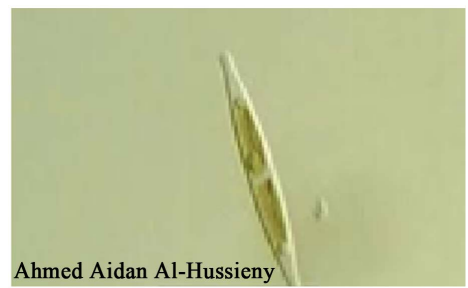

Image 36. N. minutula. 1000×.

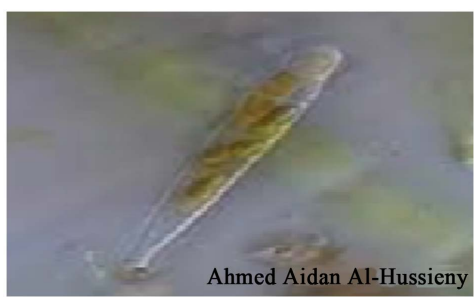

Image 37. Peronia fibula. 1000×.

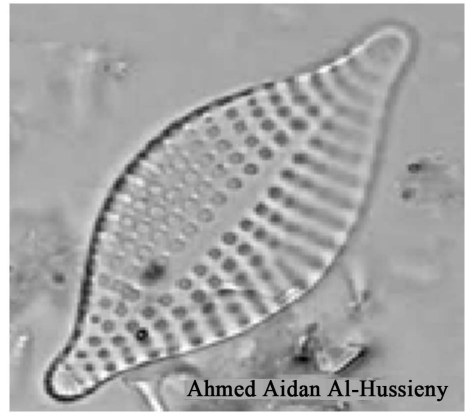

Image 38. Raphoneis amphiceros. 1000×.

35-N. littoralis. Grun.

30 - $100 \mu \mathrm{m}$ long, 13 - $30 \mu \mathrm{m}$ large and 25 - 30 in $10 \mu \mathrm{m}$ stries (Image 35).

36-N.minutula. Grun.

Cells long 15 - $25 \mu \mathrm{m}$, large 2.5 - $3 \mu \mathrm{m}$ and 12 fibules in $10 \mu \mathrm{m}$ stries (Image 36).

6-Family: Pinnulariaceae.

Genus: -Peronia.

37-Peronia fibula. Ross.

Long 20 - $50 \mu \mathrm{m}$, large 3 - $5 \mu \mathrm{m}$, and stries 15 - 17 in $10 \mu \mathrm{m}$ (Image 37).

7-Family: Raphoneisceae.

Genus: -Raphoneis.

38-Raphoneisamphiceros. Ehr.

Long 20 - $100 \mu \mathrm{m}$, large 18 - $25 \mu \mathrm{m}$, and stries 6 - 7 in $10 \mu \mathrm{m}$ (Image 38). 


\section{References}

[1] Bedair, H.M., Al-Saad, H.T. and Salmen, N.A. (2006) Iraq’s Southern Marshes Something Special to Be Conserved: A Case Study. Marsh Bulletin, 2, 99-126.

[2] Brasington, J. (2002) The Iraqi Marshlands: A Human and Environment Study. Nicholson. E. and Clark, P., Eds., Politics Publishing, London.

[3] Richardson, C.J. and Hussain, N.A. (2006) Restoring the Garden of Eden: An Ecological Assessment of the Marshes of Iraq. Bioscience, 56, 477-489. http://dx.doi.org/10.1641/0006-3568(2006)56[477:RTGOEA]2.0.CO;2

[4] Maulood, B.K., Hinton, G.C.F., Kamees, H.S., Saleh, F.A.K., Shaban, A.A. and Al Shahwani, S.M.H. (1979) An Ecological Survey of Some Aquatic Ecosystems in Southern Iraq. Tropical Ecology, 20, 27-40.

[5] Al-Kaisi, K.A. (1976) Contribution to the Algal Flora of the Rice-Fields of Southern Iraq. Nova Hedwigia, 27, 813827.

[6] Al-Saboonchi, A.A., Mohamed, A.M. and Barak, N.A. (1982) A Study of Phytoplankton in the Garma Marshes, Iraq. Iraqi Journal of Veterinary Sciences, 1, 67-78.

[7] Pankow, H. and Hadi, R.A.M. (1979) On the Algal Flora of the Marshes near Qurna. Willden, 8, 493-506.

[8] Al-Obaidi, G.S. (2006) A Study of Phytoplankton Community in Abo-Zirik Marsh, Southern Iraq. M.Sc. Thesis, University of Baghdad, Baghdad.

[9] Talib, A.H. (2009) Ecological Study on the Phytoplankton and Primary Productivity in Southern Iraqi Marshes. Ph.D. Thesis, College of Science for Women Baghdad University, $142 \mathrm{p}$.

[10] Al-Mousawi, A.H.A., Al-Saadi, H.A. and Hassan, F.M. (1994) Spatial and Seasonal Variations of Phytoplankton Population and Related Environmental in Al-Hammar Marsh. Iraq Journal of Science, 12, 9-19.

[11] Al-Saadi, H.A. and Arstonie, S.E. (1981) Primary Productivity and Phytoplankton Population Dynamics in Polluted Ashar Canal and Shatt Al-Arab, Basrah, Iraq. Vern. Internet Verein. Limnol., 21, 880-885.

[12] Hadi, R.A.M. and Haroon, A.K.Y. (1984) Diatoms of the Shatt Al-arab River, Iraq. Nova Hedwigia, 39, 513-557.

[13] Hassan, F.M., Hadi, R.A.M. and Kassim, T.I. (2012) Systematic Study Epiphytic of Algal Flora after Restoration of Al-Hawizah Marshes Southern of Iraq. International Journal of Aquatic Science, 3, 37-57.

[14] Furet, J.E. and Benson-Evans, K. (1982) An Evaluation of the Time Required to Obtain Complete Sedimentation of Fixed Algal Particales Prior to Enumeration. British Phycological Journal, 17, 253-258. http://dx.doi.org/10.1080/00071618200650271

[15] Stein, J.R. (1975) Handbook of Phycological Methods. Cambridge University Press, Cambridge.

[16] Al-Saboonchi, A.A. and Al-Saad, H.T. (1988) Check List of the Algae from Shatt Al-Arab River, Iraq. Journal of the University of Kuwait (Science), 15, 79-95.

[17] Hadi, R.A., Ismail, A.M. and Talib, A.H. (2009) Check List of the Algae in Diyala River, Iraq. Baghdad University, Um-Salama Science Journal, 6, 329-345.

[18] Ismail, A.M. and Saadalla, H.A. (2010) Seasonal Variations of the Phytoplankton Biomass in Diyala River, Iraq. Diyala Journal for Pure Sciences, 6, 142-149.

[19] Maulood, B.K., Fikrat, M.H., Al-Lami, A.A., Janan, J.T. and Abbas, M.I. (2013) Check List of Algal Flora in Iraq. Ministry of Environment, Baghdad.

[20] Al-Mahdawi, M.M. and Huda, A.A. (2013) Fifteen New Records for Fresh Water Algae of Iraq. Journal of International Scientific Publications: Ecology and Safety, 8, 574-582.

[21] Desikachary, T.V. (1959) Cyanophyta. Indian Council of Agricultural Research, New Delhi, 686 p.

[22] Prescott, G.W. (1964) The Fresh-Water Algae. William C. Brown Publishing Company, Dubuque, 222 p.

[23] Felisberto, S.A. and Rodrigues, L. (2004) Periphytic Desmids in Corumbá Reservoir, Goiás, Brazil: Genus Cosmarium Corda. Brazilian Journal of Biology, 64, 141-150. http://dx.doi.org/10.1590/S1519-69842004000100016

[24] Bellinger, E.G. and Sigee, D.C. (2010) Freshwater Algae Identification and Use as Bioindicators. Antony Rowe, Ltd., Chippenham, 285.

[25] APHA (1998) Standard Methods for Examination of Water and Wastewater. 23rd Edition, American Public Health Association, New York. 